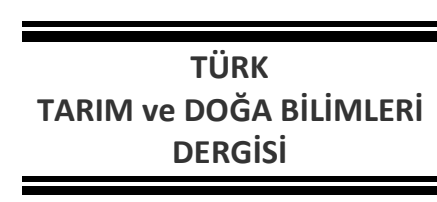

https://doi.org/10.30910/turkjans.730003

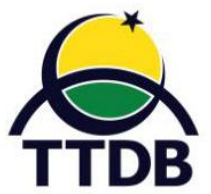

www.dergipark.gov.tr/turkjans

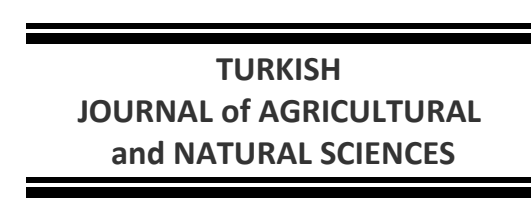

Araştırma Makalesi

\title{
Yetiştirme Sistemlerinin Beyaz Hindilerin Karkas verimlerine ve Hindi Etinin Genel Beğeni Düzeylerine Etkileri
}

\author{
Hakan inci \\ Bingöl Üniversitesi Ziraat Fakültesi Zootekni Bölümü, Bingöl Türkiye \\ hakaninci2565@hotmail.com
}

Geliş Tarihi: 30.04.2020 Düzeltme Geliş Tarihi: 05.06.2020 Kabul Tarihi: 05.06.2020

$\overline{\mathbf{O Z z}}$

Bu çalışma, kapalı ve serbest dolaşımlı sistemlerde yetiştirilen beyaz hindilerin karkas ağırlıklarının, yenilebilir iç organ ağırlıklarının ve yetiştirme sistemlerine göre etlerin duyusal analiz ve genel beğeni ve kalite özelliklerinin belirlenmesi amacıyla yürütülmüştür. Denemede günlük yaşta toplam 90 adet hindi palazı, kapalı sistem (K1), \%50 yem + mera (K2) ve Mera (K3) gruplarına 3 tekerrürlü olacak şekilde şansa bağlı olarak dağıtılmıştır. K1, K2 ve K3 gruplarının 17. hafta sonundaki karkas ağırlıkları erkek + dişi karışık (ED) olarak sırasıyla; $9252.10 \mathrm{~g}, 6979.20 \mathrm{~g}$ ve $5953.40 \mathrm{~g}$ olarak bulunmuştur $(\mathrm{P}<0.05)$. Hindi etine ait görünüş, renk, koku, lezzet ve genel beğeni gibi kalite özellikleri bakımından ise K1, K2 ve K3 gruplarının, aynı şartlarda pişirilen hindi etleri arasında genel beğeni düzeylerine ait puanlar, sırasıyla $8.00 \pm 0.32$, $9.00 \pm 0.16$ ve $9.47 \pm 0.16$ olarak hesaplanmıştır. K3 ve K2 sisteminde yetiştirilen hindilerin etleri K1 sistemde yetiştirilen hindilerin etlerinden daha fazla beğenilmiştir. $(P<0.05)$. Sonuç olarak, hindi yetiştiriciliğinde meraya dayalı yetiştiricilikte; K1 sisteminde elde edilen karkas ağırlığına kısmen yakın değerlere ulaşılabildiği, K2 ve ilk sekiz haftadan sonra tamamen mera şartlarında (K3) büyütmenin karkas özellikleri ve hayvan sağlığı açısından daha fazla tercih edildiği saptanmıştır. Bunun yanı sıra K1, K2 ve K3 olmak üzere 3 farklı yetiştirme sisteminde üretilen etler arasında en yüksek beğeni düzeyini K3 grubunun aldığı belirlenmiştir. Beğeni açısından ikinci sırayı K2 grubu almıştır. Yapılan lezzet testi sonuçlarına göre K3 grubunun K1 sisteminde yetiştirilen gruba oranla duyusal analiz ve genel beğeni ve kalite özellikleri bakımından daha yüksek beğeni düzeyine ulaştığı saptanmıştır.

Anahtar kelimeler: Yetiştirme sistemi, beyaz hindi, karkas verimi, mera.

\section{Effects of Breeding Systems on Carcass yields of White Turkeys and General Likes of Turkey Meat}

\begin{abstract}
This study was carried out to determine the carcass weights, edible internal organ weights of the white turkeys grown in closed and free range systems, and the sensory analysis and general appreciation quality characteristics of the meats according to the rearing systems. In the experiment, a total of 901 day-old turkey chick were randomly distributed to the closed system (K1), 50\% feed + pasture (K2) and Pasture (K3) groups with 3 repetitions in the daily age. Carcass weights of groups K1, K2 and K3 at the end of the 17th week were male + female mixed (ED), respectively; $9252.10 \mathrm{~g}, 6979.20 \mathrm{~g}$ and $5953.40 \mathrm{~g}$ were found $(P<0.05)$. In terms of quality characteristics such as the appearance, color, smell, taste and general taste of turkey meat, the scores of general taste of turkey meat of K1, K2 and K3 groups cooked under the same conditions; respectively, $8, .00 \pm 0, .32,9, .00 \pm 0, .16$ and $9, .47 \pm 0, .16$.. The meat of turkeys raised in the K3 and $\mathrm{K} 2$ system is more appreciated than the meat of turkeys raised in the K1 system $(P<0.05)$. As a result, in turkey farming, pasture-based farming; It was determined that values close to the weight of the carcass obtained in the K1 system can be reached, and after the first eight weeks, the growth in purely pasture conditions (K3) is more preferred in terms of carcass characteristics and animal health. In addition, it was determined that the $\mathrm{K} 3$ group received the highest taste among the meats produced in 3 different breeding systems, K1, K2 and K3. K2 group took the second place in terms of likes. According to the taste test results, it was found that the K3 group reached a higher level of appreciation in terms of sensory analysis and general taste quality characteristics compared to the group grown in the K1 system.
\end{abstract}


Key words: Breeding system, white turkey, carcass yield, pasture. Giriş

Çağımızda insan sağlığını tehdit eden ve hayvansal kaynaklı gıdalarla alınan kolesterolün özellikle kırmızı et tüketiminden kaynaklanıyor olması, insanları beyaz et tüketimine yönlendirmiştir. (Hall 1996; Cömert 2004; Anonim 2014;). Türkiye'de hayvansal protein kaynaklarımıza alternatif olabilecek ve endüstri haline gelmiş olan kanatlı yetiştiriciliği içinde tavuk ve özellikle hindi yetiştiriciliği protein açığımızın kapatılmasında önem kazanmıştır (Kırkpınar ve Mert 2004; Ekinci 2015; Karakaya ve İnci, 2014; İnci ve ark., 2018). Özellikle 1990’ı yıllarda kanatlı etinin diğer hayvan türlerine göre daha ekonomik üretiliyor olması, piliç üretiminde büyük entegrasyonların kurulması ve sözleşmeli üretim modelinin gelişmesiyle yıllık \%10 düzeyinde üretim artışının sağlandığı tavukçuluk sektörü, beyaz et kaynağı olarak talep görmüştür (Anonim 1999). Bu durumda bir ölçüde piliç eti ve son yıllarda hindi etine olan talebi arttırmıştır. Gerek hayvansal ürün mamullerini çeşitlendirmek gerekse kaliteyi yükseltmek gerekliliği açısından Türkiye'de hayvansal protein açığının kapatılması için piliç etine alternatif olarak hindi eti üretimine hIz verilmiştir. (Koçak, 1984; Anonim, 2007; Eratalar, 2008; Ekinci, 2015). Çizelge $1^{\prime}$ de Hindi etinin diğer etlerin besin madde içerikleri ile karşılaştırılması verilmiştir.

Çizelge 1. Hindi etinin diğer etlerin besin madde içerikleri ile karşılaştırılması (100 g'da)

\begin{tabular}{lcccc}
\hline & \multicolumn{2}{c}{ Kanatlı Türü } & \multicolumn{2}{c}{ Diğer Türler } \\
\cline { 2 - 5 } Besin İçeriği & Hindi Eti & Piliç Eti & Koyun Eti & Sığır Eti \\
\hline Protein (g) & 20,4 & 18,6 & 14 & 20 \\
Yağ (g) & 8 & 15,1 & 18 & 12 \\
Enerji (kcal/kg) & 160 & 215 & 228 & 194 \\
\hline
\end{tabular}

Kaynak: (Anonim, 2007; Eratalar, 2008)

Türkiye'de hindicilik, 1995'li yıllara kadar sadece geleneksel olarak mera hindiciliği tipinde olup, Tarım ve Orman Bakanlığı'na bağlı üretme istasyonlarında üretilen hindi palazlarının (Bronz ırk) yetiştiricilere dağıtılması şeklinde sürdürülmüştür. Türkiye'de hindi varlığı dünyada sayılı ülkeler arasındadır. Buna karşın, entansif hindi eti üretimi son yıllarda gelişme gösterebilmiştir. (Anonim 2006; Eratalar 2008; İnci ve ark 2013). Son yıllarda Türkiye'nin yem kaynaklarına ithalat yoluyla ödediği yüksek düzeydeki döviz sebebiyle ucuz ve doğrudan insan beslenmesinde kullanılmayan yem kaynaklarının bulunmasına yönelik çalışmalar giderek ağırlık kazanmıştır (Blake, 1993). Diğer hayvan türlerinde olduğu gibi hindi yetiştiriciliğinde de masrafların büyük çoğunluğunu yem giderleri oluşturmaktadır. Bu yüzden hindilerin dengeli beslenmesinde hangi yemin ne kadar ve nasıl verileceğinin iyi bilinmesi gerekir (Özkan ve Ergül, 1974; Sipahi, 2010). Yem giderlerinin yüksek olması nedeniyle son yıllarda tamamen kapalı olarak yapılan yetiştirme sistemlerine alternatif olarak mera hindiciliği ya da otlatmaya dayalı sistemler geliştirilmeye başlanmıştır. Mera hindiciliğin de hayvanlar çok kısa bir süre kümeste büyütüldükten sonra meraya çıkarıldıkları için yem masraflarından büyük bir tasarruf sağlanmaktadır (Anonim, 2006).

$\mathrm{Bu}$ araştırma, kapalı ve serbest dolaşımlı sistemlerde yetiştirilen beyaz hindilerin karkas ağırlıklarının, yenilebilir iç organ ağırlıklarının ve yetiştirme sistemlerine göre etlerin duyusal analiz ve genel beğeni ve kalite özelliklerinin belirlenmesi amacıyla yürütülmüştür.

\section{Materyal ve Metot}

Araştırmanın hayvan materyalini ticari bir işletmeden satın alınan 90 adet bir günlük hindi civcivi oluşturmuştur. Hindi palazları kapalı sistem (K1), \%50 yem + mera (K2) ve Mera (K3) gruplarına 3 tekerrürlü olacak şekilde şansa bağlı olarak dağıtılmıştır. Hindilere verilen farklı dönemlerdeki yemler kuru madde, enerji ve diğer besin maddeleri bakımından hindilerin yaklaşık ihtiyaçlarını karşılayabilecek şekilde düzenlenmiştir. Deneme gruplarının yem karmaları, yem hammaddelerinin ham besin maddesi analiz sonuçlarına göre ve hindilerin besin maddesi gereksinimleri NRC (1983) değerleri dikkate alınarak hazırlanmıştır. Hindilere ilk 8 hafta boyunca \%26-28 ham protein ve 2800-2900 kcal/kg ME içeren başlatma yemi, 9'uncu haftadan 14'üncü hafta 
sonuna kadar $\% 20-23$ ham protein ve $2900-3000$ $\mathrm{kcal} / \mathrm{kg} \mathrm{ME}$ içeren büyütme yemi, 15' inci haftadan denemenin tamamlandığı 17 'inci hafta sonuna kadar ise $\% 20-23$ ham protein ve 3000
$3200 \mathrm{kcal} / \mathrm{kg} \mathrm{ME}$ içeren yemle beslenmişlerdir (Çizelge 3). Çizelge 2'de K2 ve K3 gruplarındaki hindilerin yararlandığı meranın besin madde içeriği verilmiştir.

Çizelge 2. Mera besin madde içerikleri

$\begin{array}{cccccc}\begin{array}{c}\text { H. Protein } \\ (\%)\end{array} & \text { Ham Selüloz (\%) } & \text { Ham Yağ (\%) } & \text { Ham Kül (\%) } & \text { Kuru Madde (\%) } & \begin{array}{c}\text { M. Enerji } \\ (\mathrm{kcal} / \mathrm{kg})\end{array}\end{array}$

$\begin{array}{llllll}14.85 & 31.5 & 2.4 & 9.6 & 87 & 1900\end{array}$

Hindiler ilk haftadan sonra gruplara ayrılarak, 1. grup tamamen içerde ve entansif şartlarda, 2. grup çıkımdan sekizinci haftanın sonuna kadar entansif şartlarda yetiştirilmiştir ve daha sonra tamamen dışarıda yetiştirilmiş ve mera döneminde ilave olarak 1 . grubun tükettiği yemin $\% 50$ 'si verilmiştir, 3. grup ise, çıkımdan sekizinci hafta sonuna kadar içeride entansif şartlara göre yetiştirilmiş ve sekizinci haftadan sonra tamamen dışarda ve mera şartlarında beslenmiş ve ek yem verilmemiştir.

Çizelge 3. Denemede kullanılan rasyonların besin madde içerikleri

\begin{tabular}{lccc}
\hline Besin Maddeleri & $0-8$ hafta & $9-14$ hafta & $15-17$ hafta \\
\hline Ham Protein (\%) & $26-28$ & $20-23$ & $16-19$ \\
Ham Selüloz (\%) & $6-7$ & 8 & $6-7$ \\
Nem (\%) & 12 & 12 & 12 \\
Ham Kül (\%) & 8 & 8 & 8 \\
Kalsiyum (\%) & $1.0-1.5$ & $0.8-1.2$ & $1.0-1.5$ \\
Fosfor (\%) & 0.8 & 0.65 & 0.8 \\
Lizin (\%) & $1.3-1.6$ & 0.72 & 1.3 \\
Metiyonin (\%) & $0.4-0.6$ & 0.19 & 0.38 \\
Tuz (\%) & 0.35 & 0.35 & 0.35 \\
ME (kcal/kg) & $2800-2900$ & $3000-3100$ & 3200 \\
\hline
\end{tabular}

Deneme Haziran ve Ekim döneminde yürütülmüştür. Deneme süresince tamamen entansif şartlarda yetiştirilen hindiler, tel örgülerle çevrili ve altlıklı yer bölmelerinde barındırılmışlardır. Mera grupları ise ilk sekiz hafta boyunca yine aynı kümeste barındırımış ve daha sonra meraya çıkarılmışlardır. Karkas ağırlığı ve karkas özelliklerinin belirlenmesi amacıyla, her gruptan 10'ar adet olmak üzere toplam 30 adet hayvan kesilmiştir. Karkas ağırlıkları, karkas parçaları (but, göğüs, kanat, sırt, boyun) ve yenilebilir iç organ ağırıkları (taşlık, karaciğer, kalp) alınmıştır. Karkas öğelerine ayırma işlemi "Kentucky" yöntemine göre uygulanmış olup, etlerin lezzet testi için ise duyusal analiz yapılmıştır. Duyusal analiz için, deneme gruplarına ait karkasların göğüs ve but parçalarından rastgele seçilen $10^{\prime}$ ar adedi, ayrı ayrı kaplarda fırında aynı şartlarda pişirilmiştir.
Pişirilen göğüs ve but parçalarının etleri aynı şekilde numaralandırılmış tabaklara bırakılmıştır. 20-50 yaş grubu arasından seçilen, 15 paneliste duyusal analiz hakkında bilgi verilmiş ve panelistler birbirini etkilemeyecek şekilde oturtulmuştur. Ayrı ayrı tabaklarda servis yapılan hindi eti tattırılmış, dağıtılan formlara (Çizelge 4) tabak numaralarını yazarak, genel beğenilerini, etinin lezzetini, kokusunu, rengini, görünümünü değerlendirerek 1'den 10'a kadar puan vermeleri istenmiştir (Özdemir, 2007) İncelenen özelliklere ait veriler SAS (1988) istatistik paket programında analiz edilmiştir. Üç grubun arasındaki farklar hesaplanırken $F$ testi, iki grubun arasındaki farklar için $T$ testi uygulanmış olup, ortalamalar arasındaki farklılıkların önemlilik derecelerinin tespitinde ise Duncan testi kullanılmıştır. 
Çizelge 4. Duyusal analiz için hazırlanan form

\begin{tabular}{lllllllllll}
\hline Özellikler & $\mathbf{1 0}$ & $\mathbf{9}$ & $\mathbf{8}$ & $\mathbf{7}$ & $\mathbf{6}$ & $\mathbf{5}$ & $\mathbf{4}$ & $\mathbf{3}$ & $\mathbf{2}$ & $\mathbf{1}$ \\
\hline Görünüm & & & & & & & & & \\
Renk & & & & & & & & & \\
Koku & & & & & & & & & \\
Lezzet & & & & & & & & & \\
Genel Beğeni & & & & & & & & & & \\
\hline
\end{tabular}

10: en yüksek 1: en düşük

\section{Bulgular}

\section{Karkas Verimi ve Karkas Özellikleri}

K1, K2 ve K3 gruplarına ait karkas ağırıkları erkeklerde sırasıyla; 9876.00 \pm 22316 . $7700.20 \pm 223.16$ ve $6387.40 \pm 223.16 \mathrm{~g}$ olmuş ve ortalamalar arasındaki farklılıklar önemli $(P<0.05)$ bulunmuştur. Dişilerde karkas ağırlıkları aynı sirayla; $8628.20 \pm 248.40,6258.20 \pm 248.40$ ve $5519.40 \pm 248.4 \mathrm{~g}$ olarak bulunmuş ve ortalamalar arasındaki farklılıklar önemli $(P<0.05)$ olmuştur. Yine sırayla; erkek + dişi karışık cinsiyette $9252.10 \pm 165.44,6979.20 \pm 165.44$ ve $5953.40 \pm 165.4 \mathrm{~g}$ ve muamele gruplarının karkas ağırlıkları arasındaki farklılıklar önemli $(P<0.05)$ bulunmuştur. On yedi hafta sonunda K1, K2 ve K3 gruplarına ait hindilerin karkas randımanları arasındaki farklılıklar önemli $(P<0,05)$ olarak bulunmuştur. Muamele gruplarının erkek + dişi karışı cinsiyette ortalama randımanları sırayla; $\% 81.51 \pm 2.35, \quad \% 75.98 \pm 2.35$ ve $\% 76.52 \pm 2.35$ olarak saptanmıştır. But ağırlıkları arasındaki farklılıklar önemli $(P<0,05)$ olarak saptanmıştır. K1, K2 ve K3 gruplarında erkek hindilerin sırayla; $2472.00 \pm 84.63, \quad 2029.20 \pm 84.63$ ve $1800.80 \pm 84.63$ g olarak bulunmuş ve ortalamalar arasındaki farklılıklar önemli $(P<0,05)$ olarak saptanmıştır. Dişilerde aynı sırayla;

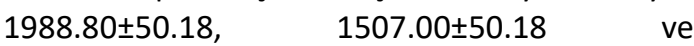
$1445.00 \pm 50.18 \mathrm{~g}$ olarak saptanmış, kapalı sistem grubunun diğer muamele gruplarına göre ortalamalar arasındaki farklılığının önemli $(P<0,05)$ olduğu bulunmuştur. K1, K2 ve K3 gruplarında sırayla; erkek + dişi karışık cinsiyette $2230.40 \pm 48.78, \quad 1768.10 \pm 48.78$ ve $1622.90 \pm 48.78 \mathrm{~g}$ olup, ortalamalar arası farklılıkların önemli $(P<0,05)$ olduğu saptanmıştır. Muamele gruplarının göğüs ağırlıkları incelendiğinde ortalamalar arasındaki farklılıkların önemli $(P<0,05)$ olduğu gözlenmiştir. K1, K2 ve K3 gruplarının erkek hindileri sırayla; $3468.00 \pm 79.66 \mathrm{~g}, \quad 2682.20 \pm 79.66 \mathrm{~g}$ ve
1908.20 $\pm 79.66 \mathrm{~g}$ bulunmuş ve gruplar arasındaki farklılıklar önemli $(P<0,05)$ olarak saptanmıştır. Dişilerde aynı sıraya göre; 3239.00 \pm 108.40 , $2235.60 \pm 108,40$ ve $1719.00 \pm 108,40 \mathrm{~g}$ olarak bulunmuş, erkek + dişi karışık cinsiyette sırayla;

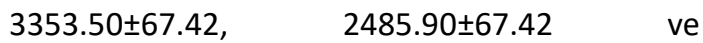
$1813.60 \pm 67.42 \mathrm{~g}$ olarak bulunmuş ve ortalamalar arasındaki farklılıklar önemli $(P<0,05)$ olarak bulunmuştur. K1, K2 ve K3 gruplarında ortalama kanat ağırlıkları incelendiğinde, kapalı sistemde yetiştirilen hindilerin diğer muamele gruplarında yetiştirilenlere göre ortalamaları arasındaki farklılıkların önemli $(P<0,05)$ olduğu bulunmuştur. Sırayla erkek + dişi karışık cinsiyette $1108.80 \pm 19,58, \quad 879.40 \pm 19.58$ ve $828.80 \pm 19.58 \mathrm{~g}$ olup ve ortalamalar arasındaki farklılıklar önemli $(P<0,05)$ olarak saptanmıştır. Sırt ağırıkları bakımından K1, K2 ve K3 grupların

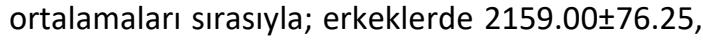
$1648.60 \pm 76.25$ ve $1379.80 \pm 76.25 \mathrm{~g}$ olmuş ve ortalamalar arasındaki farklılıklar önemli $(P<0,05)$ bulunmuştur. Dişilerde sırayla; 2003.20 \pm 88.84 , $753.40 \pm 88.84$ ve $1301.40 \pm 88.84 \mathrm{~g}$ olarak saptanmış ve muamele grupları arasındaki farklılıklar önemli $(P<0,05)$ bulunmuştur. Karışık cinsiyette incelendiğinde ortalamalar arasındaki farklılıklar önemli $(P<0,05)$ olarak bulunmuştur. Karaciğer ağırlıkları incelendiğinde, muamele grupları arasındaki farklılıklar önemsiz bulunmuştur. K1, K2 ve K3 gruplarının erkek + dişi karışık cinsiyette ortalama ağırlıklar sırayla; $109.00 \pm 4.58,118.90 \pm 4.58$ ve $113.90 \pm 4.58 \mathrm{~g}$ olarak saptanmıştır. Yetiştirme sistemlerinin taşlık ağırlıkları arasındaki farklılıkların önemli $(P<0,05)$ olduğu saptanmıştır. Serbest dolaşımlı sistemlerde bulunan hindilerin taşlık yapısının daha iyi geliştiği gözlenmiştir. K1, K2 ve K3 gruplarının erkek + dişi karışık cinsiyette sırayla; $120.60 \pm 6.13,129.90 \pm 6.13$ ve $143.80 \pm 6.13 \mathrm{~g}$ olarak saptanmıştır (Çizelge 5). 
Çizelge 5. Muamele gruplarına ait hindilerin 17 hafta sonundaki karkas özellikleri ve yenilebilir iç organ ağırlıkları (g)

\begin{tabular}{|c|c|c|c|c|c|c|c|c|}
\hline & & K1 & & K2 & & K3 & & \\
\hline & Cins & $X \pm S x$ & $\mathrm{n}$ & $X \pm S x$ & $\mathrm{n}$ & $X \pm S x$ & $\mathrm{n}$ & $\mathrm{P}$ \\
\hline \multirow{3}{*}{ Karkas Ağırlığı, g } & $E$ & $9876.00 \pm 223.16 a$ & 5 & $7700.20 \pm 223.16 b$ & 5 & $6387.40 \pm 223.16 c$ & 5 & * \\
\hline & D & $8628.20 \pm 248.40 a$ & 5 & $6258.20 \pm 248.40 b$ & 5 & $5519.40 \pm 248.40 b$ & 5 & $*$ \\
\hline & $\mathrm{K}$ & $9252.10 \pm 165.44 a$ & 10 & $6979.20 \pm 165.44 b$ & 10 & $5953.40 \pm 165.44 c$ & 10 & $*$ \\
\hline \multirow{3}{*}{ Karkas Randımanı, \% } & $E$ & $82.27 \pm 3.31 a$ & 5 & $75.05 \pm 3.31 b$ & 5 & $74.78 \pm 3.31 b$ & 5 & $*$ \\
\hline & D & $80.67 \pm 1.77 a$ & 5 & $77.16 \pm 1.77 b$ & 5 & $78.64 \pm 1.77 b$ & 5 & $*$ \\
\hline & $\mathrm{K}$ & $81.51 \pm 2.35$ & 10 & $75.98 \pm 2.35 b$ & 10 & $76.52 \pm 2.35 b$ & 10 & $*$ \\
\hline \multirow{3}{*}{ But Ağırlığı, g } & $E$ & $2472.00 \pm 84.63 a$ & 5 & $2029.20 \pm 84.63 b$ & 5 & $1800.80 \pm 84.63 \mathrm{~b}$ & 5 & $*$ \\
\hline & D & $1988.80 \pm 50.18 a$ & 5 & $1507.00 \pm 50.18 b$ & 5 & $1445.00 \pm 50.18 \mathrm{~b}$ & 5 & $*$ \\
\hline & K & $2230.40 \pm 48.78 a$ & 10 & $1768.10 \pm 48.78 \mathrm{~b}$ & 10 & $1622.90 \pm 48.78 \mathrm{c}$ & 10 & $*$ \\
\hline \multirow{3}{*}{ Göğüs Ağırlığı, g } & $E$ & $3468.00 \pm 79.66 a$ & 5 & $2682.20 \pm 79.66 b$ & 5 & $1908.20 \pm 79.66 c$ & 5 & $*$ \\
\hline & D & $3239.00 \pm 108.40 a$ & 5 & $2235.60 \pm 108.40 b$ & 5 & $1719.00 \pm 108.40 c$ & 5 & $*$ \\
\hline & K & $3353.50 \pm 67.42 a$ & 10 & $2458.90 \pm 67.42 b$ & 10 & $1813.60 \pm 67.42 c$ & 10 & * \\
\hline \multirow{3}{*}{ Kanat Ağırlığı, g } & $E$ & $1259.40 \pm 31.47 a$ & 5 & $1005.40 \pm 31.47 \mathrm{~b}$ & 5 & $941.80 \pm 31.47 \mathrm{~b}$ & 5 & $*$ \\
\hline & D & $958.20 \pm 23.46 a$ & 5 & $753.40 \pm 23.46 b$ & 5 & $715.80 \pm 23.46 \mathrm{~b}$ & 5 & $*$ \\
\hline & $\mathrm{K}$ & $1108.80 \pm 19.58 a$ & 10 & $879.40 \pm 19.58 b$ & 10 & $828.80 \pm 19.58 b$ & 10 & $*$ \\
\hline \multirow{3}{*}{ Sırt Ağırlığı, g } & $E$ & $2159.00 \pm 76.25 a$ & 5 & $1648.60 \pm 76.25 b$ & 5 & $1379.80 \pm 76.25 c$ & 5 & * \\
\hline & D & $2003.20 \pm 88.84 a$ & 5 & $1407.60 \pm 88.84 b$ & 5 & $1301.40 \pm 88.84 \mathrm{~b}$ & 5 & $*$ \\
\hline & K & $2081.10 \pm 57.36 a$ & 10 & $1528.10 \pm 57.36 b$ & 10 & $1340.60 \pm 57.36 \mathrm{c}$ & 10 & * \\
\hline \multirow{3}{*}{ Kalp Ağırlığı, g } & $E$ & $49.40 \pm 2.34 a$ & 5 & $37.40 \pm 2.34 b$ & 5 & $30.80 \pm 2.34 b$ & 5 & * \\
\hline & D & $37.80 \pm 1.65 a$ & 5 & $29.80 \pm 1.65 b$ & 5 & $24.60 \pm 1.65 c$ & 5 & * \\
\hline & K & $43.60 \pm 1.43 a$ & 10 & $33.60 \pm 1.43 b$ & 10 & $27.70 \pm 1.43 c$ & 10 & $*$ \\
\hline \multirow{3}{*}{ Karaciğer Ağırlığı, g } & $E$ & $125.60 \pm 7.84 a$ & 5 & $133.20 \pm 7.84 a$ & 5 & $128.60 \pm 7.84 a$ & 5 & Önz \\
\hline & D & $92.40 \pm 5.39 a$ & 5 & $104.60 \pm 5.39 a$ & 5 & $99.20 \pm 5.39 a$ & 5 & Önz \\
\hline & K & $109.00 \pm 4.58 a$ & 10 & $118.90 \pm 4.58 a$ & 10 & $113.90 \pm 4.58 a$ & 10 & Önz \\
\hline \multirow{3}{*}{ Taşıı Ağırlığı, g } & $E$ & $114.40 \pm 10.01 b$ & 5 & $137.80 \pm 10.01 \mathrm{ab}$ & 5 & $157.20 \pm 10.01 a$ & 5 & $*$ \\
\hline & D & $126.80 \pm 5.38 a$ & 5 & $122.00 \pm 5.38 a$ & 5 & $130.40 \pm 5.38 a$ & 5 & Önz \\
\hline & K & $120.60 \pm 6.13 b$ & 10 & $129.90 \pm 6.13 a$ & 10 & $143.80 \pm 6.13 a$ & 10 & $*$ \\
\hline
\end{tabular}

a,b: Aynı satırda farklı harfle gösterilen ortalamalar arasındaki farklııklar önemlidir. P: Önem düzeyi,

*: P<0,05,Önz: Önemsiz, n: Hayvan sayısı, E: Erkek, D: Dişi, K: Erkek +Dişi

\section{Duyusal Analiz}

Hindi etine ait görünüş, renk, koku, lezzet ve genel beğeni gibi kalite özelliklerinin tüketici tarafından beğenilme düzeyinin değerlendirilmesi amacıyla düzenlenmiş olan duyusal analiz testinin sonuçları Çizelge 6'da verilmiştir. Genel puanlamada gruplar ortalama olarak 8-9,5 arasında (çok iyi) puan almışlardır. K1, K2 ve K3 olmak üzere 3 farklı ortamda yetiştirilen ve aynı şartlarda pişirilmiş olan hindi etleri arasında genel beğeni düzeyinde sırasıyla $8.00 \pm 0.32,9.00 \pm 0.16$ ve $9.47 \pm 0.16$ puanlar almışlardır. K3 ve K2 sisteminde yetiştirilen hindilerin etleri K1 sistemde yetiştirilen hindilerin etlerinden daha fazla beğenilmiştir ve ortalamalar arasındaki fark önemli $\quad(P<0,05)$ bulunmuştur.

Çizelge. 6. Deneme gruplarına ait hindi etlerinin bazı genel beğeni kriterleri ve fiziksel özellikleri

\begin{tabular}{lccc} 
& \multicolumn{3}{c}{ Yetiştirme Sistemleri } \\
\cline { 2 - 4 } & $\begin{array}{c}\mathrm{K} 1 \\
(\mathrm{X} \pm \mathrm{Sx})\end{array}$ & $\begin{array}{c}\mathrm{K} 2 \\
(\mathrm{X} \pm \mathrm{Sx})\end{array}$ & $\begin{array}{c}\mathrm{K} 3 \\
(\mathrm{X} \pm \mathrm{Sx})\end{array}$ \\
\hline Görünüş & $8.40 \pm 0.23 \mathrm{~b}$ & $9.27 \pm 0.18 \mathrm{a}$ & $9.53 \pm 0.16 \mathrm{a}$ \\
Renk & $7.67 \pm 0.15 \mathrm{~b}$ & $8.40 \pm 0.19 \mathrm{a}$ & $8.80 \pm 0.24 \mathrm{a}$ \\
Koku & $7.87 \pm 0.27 \mathrm{~b}$ & $8.60 \pm 0.19 \mathrm{a}$ & $8.80 \pm 0.24 \mathrm{a}$ \\
Lezzet & $7.80 \pm 0.36 \mathrm{~b}$ & $8.80 \pm 0.20 \mathrm{a}$ & $9.33 \pm 0.21 \mathrm{a}$ \\
Genel beğeni & $8.00 \pm 0.32 \mathrm{~b}$ & $9.00 \pm 0.16 \mathrm{a}$ & $9.47 \pm 0.16 \mathrm{a}$
\end{tabular}




\section{Tartışma ve Sonuç}

Kanatlı hayvanlarda et içerisinde en önemli kısımları but, göğüs ve kanat oluşturmaktadır. Muamele gruplarına ait hindilerin karkas ağırlıkları, K1, K2 ve K3 grupları için erkeklerde sırasıyla; $9876 \pm 223.16$, $7700.20 \pm 223.16$ ve $6387.40 \pm 223,16 \mathrm{~g}$ ve ortalamalar arasındaki farklılıklar önemli $(P<0,05)$, dişilerde yine aynı sırayla 8628.20 $\pm 248.40, \quad 6258.20 \pm 248.40 \quad$ ve $5519.40 \pm 248.4 \mathrm{~g}$ ve ortalamalar arasındaki farklılıklar K2 ve K3 grupları arasında önemsiz, K1 grubu ile diğerleri arasında önemli $(P<0,05)$ bulunmuştur. Erkek + Dişi karışık cinsiyette ise karkas ağırlıkları sırayla; 9252.10 \pm 165.44 , $6979.20 \pm 165.44$ ve $5953.40 \pm 165.44 \mathrm{~g}$ ve ortalamalar arasındaki farklılıklar önemli $(P<0,05)$ olmuştur. Hindilerin karkas ağırlıklarının yetiştirme sisteminden önemli düzeyde etkilendiği gözlenmiştir. But ağırlıkları bakımından erkeklerde K2 ve K3 grupları arasındaki farklılık önemsiz, K1 sistem grubu ile diğer gruplar arasındaki farklılıklar önemli $(P<0,05)$ bulunmuştur. Göğüs ağırlığı bakımından muamele gruplarına ait bulgular arasındaki farklılıklar erkek, dişi ve erkek + dişi karışık cinsiyet bakımından önemli $(P<0,05)$ bulunmuştur. Kanat ağırlığı bakımından gruplar arasındaki farklılıklar K2 ve K3 grupları arasında önemsiz, Kapalı sistem grubu ile diğerleri önemli $(P<0,05) \quad$ olmuştur. Karaca ve ark (1991) hindilerde büyütme döneminde meraya dayalı yetiştirmenin gerek yem tüketimi, gerekse karkas kalitesi bakımından daha avantajlı olduğu, karkas ağırlığı bakımından ise kapalı sisteme yakın değerler elde edildiğini bildirmişlerdir. Aksoy ve ark (1996), Bronz hindilerin otlatmaya dayalı besi uygulamasında istenilen büyüklükte karkas ağırlığına ulaşıldığını ve yem maliyetinde önemli oranlarda azalmaların gözlendiğini açıklamışlardır. Şengül ve ark (1999), entansif ve yarı entansif şartlarda, 16 haftalık besi dönemi boyunca yetiştirilen Bronz hindilerin canlı ağırlıklarına ait bulgular arasındaki farklıı̆ı̆ın önemli düzeyde olmadığını, meraya çıkarılan hindilerin sürekli kümeste beslenenlere oranla daha az yem tükettiklerini ve hindilerin meradan oldukça iyi yararlandıklarını bildirmişlerdir. Bu çalışmadan elde edilen bulgular Aksoy ve ark (1996), Şengül ve ark (1999) ve Karaca ve ark (1991)'nin bildirdikleri sonuçlarla büyük ölçüde benzerlik göstermektedir. Porkhorst and Mountrey (1998), hindilerin uygun mevsim koşullarında mera ortamında büyütülmelerinde Kapalı sisteme nazaran daha fazla canlı ağırlık kazandıklarını, uygun mera koşullarında yemden yararlanma, büyüme gelişme gibi performans değerlerinin istenilen düzeylerde olabildiğini belirtmişlerdir.

Gatchalian (1999) ve Özdemir (2007) kanatlı etlerinin duyusal analiz bakımından değerlendirmesinde üzerinde durulması gereken kriterler arasında görünüş, tat, koku, yapı ve işitme duyusuyla tespit edilen puanlamaların bulunduğunu belirtmişlerdir. Araştırmamızda uygulanan lezzet değerlendirmesi, Peryam and Pilgrim (1957), Xu (1999), Poste (1990), Turhan (1992) ve Reilly and York (2001) tarafindan açıklandığı şekilde yapılmıştır. Hindi etlerinin görünüş, renk, koku, lezzet ve genel beğeni gibi kalite özelliklerinin tüketici tarafından beğenilme düzeyi değerlendirildiğinde; K1, K2 ve K3 olmak üzere 3 farklı yetiştirme sisteminde üretilen etler arasında en yüksek beğeni düzeyini $\mathrm{K} 3$ grubunun aldığı belirlenmiştir. Beğeni açısından ikinci sırayı K2 grubu almıştır. Özer ve Özbey (2013) 'de entansif ve yarı entansif sistemde beslenen Beyaz hindilerde yapılan lezzet testi sonuçlarına göre merada beslenen yarı entansif grubun entansif gruba oranla daha iyi olduğu bildirilmiştir. Sonuç olarak, hindi yetiştiriciliğinde tamamen kapalı sistemlerin giderler göz önüne alındığında avantajlı olmayacağı, uygun mevsim ve mera koşullarında tamamen mera şartlarında ya da münavebeli içeri dışarı sistemlerinin uygulanmasıyla büyük oranda avantaj sağlanabileceği söylenebilir. Bunun yanı sıra meraya dayalı yetiştiricilikte kapalı sistemlerde elde edilen karkas ağırlığına yakın değerlere ulaşılabildiği, \%50 yem + mera ve ilk sekiz haftadan sonra tamamen mera şartlarında büyütmenin karkas özellikleri, lezzet ve genel beğeni gibi kalite özellikleri açısından daha fazla tercih edildiği söylenilebilir.

\section{Kaynaklar}

Aksoy, Ş., Aksoy, T., İşcan, N., Tekirdağ ilindeki otlatmaya dayalı hindi besiciliğinde maliyet analizi, I. Ulusal Zootekni Kongresi, T.C. Ziraat Bankası Kültür Yayınları, Antalya, 29(2): 48-54, 1996.

Anonim, 2014. Hindi Yetiştiriciliği, Uluslararası Tarım ve Gıda Konfederasyonu.

Anonim, 2006. Kanatlı verileri yıllı̆̆, Besd-Bir, Ankara,

Anonim, 2007. Tarımsal işletmeler genel müdürlüğü bilgi belge merkezi (TiGEM),

Anonim, 1999. TC Başbakanlık DPT. 8. beş yıllık kalkınma planı. Hayvancılık Ö.i..K. Kanatlı kümes hayvanları yetiştiriciliği grubu, 6 . Bölüm. s; 75-92. "Hayvancılık ekonomisi grubu”, 9. Bölüm. s; 134. Ankara, 1999. 
Blake, IP., 1993. Tavukçuluk artıklarının değerlendirilme yöntemleri, Uluslararası Tavukçuluk Kongresi 93, İstanbul. 106107,

Cömert, N., 2004. Mısır-soya esaslı etlik erkek hindi yem karmalarına katılan avilamycin, bio-moss, cylactin, yucca schidigera ekstraktının besi performansı, kesim sonuçları ile bazı kan ve bağırsak parametreleri üzerine etkileri, (Basılmamış Doktora Tezi)

Ekinci, Y., 2015. Batman ili entansif koşullarında yapılan hindi yetiştiriciliğinin genel yapısı, B.Ü. Fen Bilimleri Enst. (Basılmamış Yüksek Lisans Tezi)

Eratalar, SA., 2008. Beyaz hindilerde yerleşim sıklığının performans, karkas kalitesi ve bazı stres parametrelerine etkisi, (Basılmamış Doktora Tezi),

Gatchalian, MM., 1999. Quality assesment through statistically based sensory evaluation methods, The TQM Magazine, 11(6): 389-396,

Hall, S., 1996. Turkeys turned meat-machines", (www.earthsave.ca)

İnci, H., Taysı, R., Sevinç, EH., 2013. Bingöl ili hindi yetiştiriciliğinin mevcut durumu ve sorunları", Tr. Doğa ve Fen Derg.Tr.J.Nature Sci., 2(1): 85-89,

İnci, H., Küçükbayrak, U., Karakaya, E., Aydın, A. 2018. Diyarbakır illi Hindi Yetiştiriciliğinin Yapısı. Uluslararası Doğu Akdeniz Tarımsal Araştırma Enstitüsü Dergisi, 1(1): 20-32.

Karaca, O., Vanlı, Y., Demirel, M., Eratak, S., Çetin, M., Aydın, A., 1991. Bronz ırkı hindilerin kapalı ve açık yetiştirme koşullarında gelişme ve karkas özellikleri üzerine araştırmalar, Yüzüncü Yıl Üniversitesi Ziraat Fakültesi Dergisi, Van,

Karakaya E., İnci, H. 2014. Bingöl ili Merkez İlçesi Hane Halkının Kanatlı Eti Tüketim Tercihleri. U. Ü. Ziraat Fakültesi Dergisi, 2014, Cilt 28, Sayı 1, 53-64

Kırkpınar, F., Mert, S., 2004. Etlik hindi üretiminin temel ilkeleri, Hasad Hayvancılık Dergisi, 2(9): 24-27,

Koçak, Ç., 1984. Hindi yetiştiriciliği, T.C. Tarım ve Köy İşleri Bakanlığı Teşkilatlanma ve Destekleme Genel Müdürlüğü, Yayın No; 7, Ankara,

Özdemir, G., 2007. Kaya kekliklerinin (Alectoris graeca) yer ve kafes sistemlerinde büyüme, besi performansı ve karkas özellikleri, F.Ü. Sağlık Bilimleri Est. (Doktora Tezi),
Özer, H., Özbey, O., 2013. Beyaz ve bronz hindilerin (Meleagris gallopavo) entansif ve yarı entansif şartlarda bazı verim özellikleri: II. kesim ve karkas özellikleri, Fırat Üniversitesi Sağlık Bilimleri Veteriner Dergisi 27(3): 135-140,

Özkan, K., Ergül, M., 1974. Kasaplık piliç karmalarında soya küspesi yerine pamuk tohum küspesi kullanılma imkanları, Ege Üni. Zir. Fak. Dergisi. 11(1): 147-157,

Peryam, DR. and Pilgrim, FJ., 1957. Hedonic scale method for measuring food preferences, Food Technology, 11; 9-14,

Porkhorst, CR, Mountrey, GS., 1998. Poultry meat and egg production, Newyork, NY,

Poste, LM., 1990. A Sensory perspective of effect of feeds on flavour in meats, poultry meats", Journal of Animal Science, 68; 4414-4420

Reilly, TI. and York, RK., 2001. Guidance on Sensory Testing and Monitoring of Seafood for Presence of Petroleum Taint Following an Oil Spill, NDAA Technical Memorandum NOS OR\&R, No:9. Washington, USA,

Sipahi, C., 2010. Entansif hindi yetiştiriciliği işletmelerinde kârlılık ve verimlilik analizleri, Hayvan Sağlığı Ekonomisi Ve İşletmeciliği Anabilim Dalı Doktora Tezi. Türkiye Cumhuriyeti. Ankara Üniversitesi. Sağlık Bilimleri Enstitüsü

Şengül, T., Yurtseven, S., Polat, T., 1999. Entansif ve yarı entansif koşullarda (Özel Olarak Tesis Edilmiş Hindi Mer'alarında) yetiştirilen bronz hindilerin besi performansları ve karkas özellikleri yönünden karşılaştırılması, Turk J Vet Anim Sci, 23(3): 489-493

Turhan, K., 1992. Potasyum sorbat ve laktik asitin vakum paketlenmiş tavuk etlerinin raf ömrüne etkisi. Yüksek Lisans Tezi, Ankara Üniversitesi Gıda Mühendisliği Fakültesi, Gıda Bilimi ve Teknolojisi ABD. Ankara.

$\mathrm{Xu}$, L., 1999. The removal of phenolic compounds for the production of high quality canola protein isolates, Graduate Department of Chemical Engineering and Applied Chemistry, University of Toronto. Canada. 